\title{
Gastric Electrical Stimulation for Gastroparesis
}

\author{
Edy E Soffer \\ Cedars Sinai Medical Center, Los Angeles, CA, USA
}

Gastric electrical stimulation (GES) for gastroparesis has been in use for more than a decade. Multiple publications, consisting almost entirely of open label single center studies, reported a beneficial effect on symptoms, quality of life and nutritional status. Some predictors of better response to GES have been lately identified, primarily diabetic etiology and nausea and vom iting as the predominant symptoms. However, individual response to GES remains difficult to predict. The mechanism of action of GES remains poorly understood. Stimulation parameters approved in clinical practice do not regulate gastric slow wave activity and have inconsistent effect on gastric emptying. Despite such limitations, gastric electrical stimulation remains a helpful intervention in some patients with severe gastroparesis who fail to respond to medical therapy.

\section{(J Neurogastroenterol Motil 2012;18:131-137)}

Key Words

Electrical stimulation; Gastric emptying; Gastroparesis

\section{Introduction}

Electrical stimulation of the gut was introduced almost 5 decades ago in an attempt to treat postoperative ileus. ${ }^{1}$ Later studies showed that gastric electrical stimulation (GES) with long duration pulses (in milliseconds) could pace the stomach, ${ }^{1,2}$ enhance gastric emptying ${ }^{3,4}$ and normalize gastric dysrhythmia. ${ }^{2,5,6}$ Gastric electrical stimulation was consequently introduced in clinical practice worldwide as a treatment option for patients with recalcitrant gastroparesis. Clinical experience with GES has been reported by multiple studies, mostly from single centers. This article reviews technical aspects of GES, and the clinical data and status of this intervention for the treatment of gastroparesis.

\section{Technical Aspects of Gut Electrical Stimulation}

A number of technical variables determine the effect of electrical stimulation on gut tissue. Parameters of waveform applied by the pulse generator (shape, amplitude and frequency) and consequently the energy delivered to the tissue are among the most important in determining tissue response. The electromechanical properties of the delivery system (the electrodes) are also important.

Two types of electrical stimulation have been used for gastroparesis. One type is referred to as a long-pulse duration and applies pulses with duration in milliseconds (usually few hundreds), at a frequency of a few cycles per minute. Hence, it is also commonly referred to as low-frequency stimulation, or high energy stimulation, since the amount of energy delivered to the tissue de-

Received: January 28, 2012 Revised: March 17, 2012 Accepted: March 24, 2012

(c) This is an Open Access article distributed under the terms of the Creative Commons Attribution Non-Commercial License (http://creativecommons. org/licenses/by-nc/3.0) which permits unrestricted non-commercial use, distribution, and reproduction in any medium, provided the original work is properly cited.

*Correspondence: Edy E Soffer, MD

Center for Digestive Diseases, GI Motility Program, 8730 Alden Drive, Thalians. Building, 2nd floor East, Los Angeles, CA 90048, USA

Tel: +1-310-423-6143, Fax: +1-310-423-8356, E-mail: edy.soffer@cshs.org

Financial support: None.

Conflicts of interest: None. 
pends, among others, on the product of pulse duration and its frequency. This waveform can entrain gastric slow waves (pace the stomach) and enhance gastric emptying (Fig. 1). ${ }^{2}$ The high power consumption of this type of stimulation has limited its clinical use. The second type of stimulus is referred to as a shortpulse duration, and applies pulses with duration in microseconds, at a hertz frequency (cycle/sec), hence also referred to as high-frequency stimulation or low energy stimulation. Pulses can be delivered continuously, or in groups (trains). GES with trains of high frequency, short-duration pulses is currently the only type in clinical use for gastroparesis (Fig. 2).

The structure of electrodes is also a factor in the choice of pulse parameters. It is important to ensure that the maximal electrical charge applied at any time point on the electrodes will not exceed the maximum charging of the electrode-tissue capacitance. ${ }^{7,8}$ Exceeding this limit results in electrolysis, damage to the electrodes and formation of toxic electrochemical products in the tissue. Increased capacitance can be achieved by coating wires (such as platinum) with iridium oxide or changing pulse parameters by reducing pulse amplitude or shortening pulse duration in order to reduce total charge.
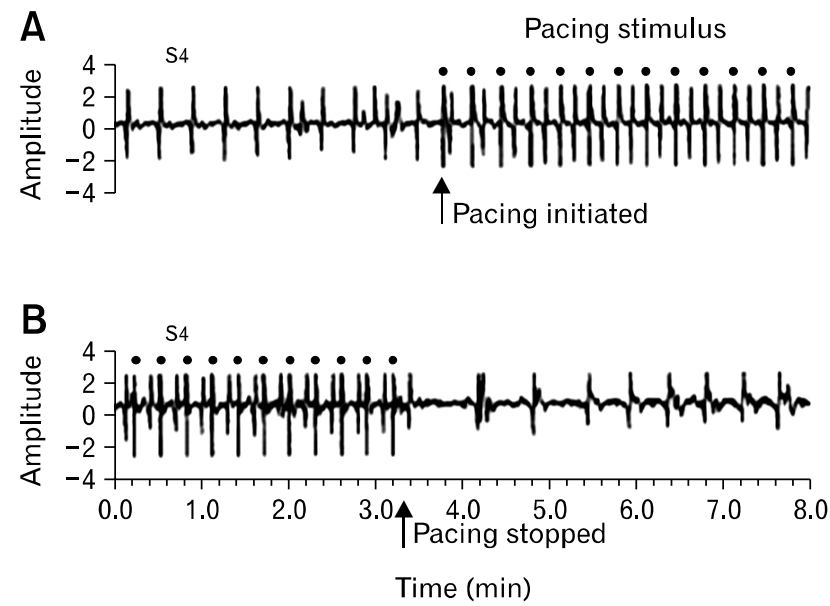

Figure 1. Gastric electrical stimulation in a patient with gastroparesis. The recording is obtained from an electrode positioned in the antrum (S4), while stimulation is delivered through an electrode positioned in the mid body of the stomach. Pacing stimuli, marked by dots, drive the electrical frequency as recorded in the antrum on a 1:1 ratio, indicating pacing (entrainment). In this experiment, stimulation with rectangular pulses of $30 \mathrm{~ms}$, amplitude of $4 \mathrm{~mA}$ and frequency up to $10 \%$ higher than the intrinsic gastric frequency was able to completely entrain the gastric slow wave and normalize gastric dysrhythmia. This stimulus is referred to as long pulse duration/low frequency, and also as high energy (reproduced from Lin et $\mathrm{al}^{2}$ ).

\section{The Evolution of Gastric Electrical Stimulation}

Interest in electrical stimulation was driven by the knowledge that the gastrointestinal (GI) tract throughout most of its length has natural pacemakers, and hence, application of electrical stimuli can modulate the myoelectric activity that they generate. Bilgutay et $\mathrm{al}^{9}$ tested the use of electrical stimulation of the GI tract to treat ileus, and found that application of electrical stimuli to the stomach, via the tip of a nasogastric tube, resulted in augmentation of gastric contractions and increased gastric emptying, as assessed by fluoroscopy. This initial impression was not confirmed by subsequent randomized controlled studies, that failed to show a significant effect of electrical stimulation on the duration of postoperative ileus. ${ }^{10,11}$ Subsequent research shed light on gastrointestinal myoelectric activity and its relation to contractile activity, ${ }^{1,12-15}$ and showed that electrical stimulation of the stomach could control (entrain) gastric electrical activity. Further observations showed that optimal pacing could be achieved with stimulation at a frequency that was slightly higher than the natural intrinsic gastric slow wave frequency of humans or canines, and with pulse duration in the range of milliseconds (Fig. 2), and could also improve gastric emptying in health and disease. ${ }^{2-4,15,16}$ Later studies, using short duration pulses (in microseconds) and at higher frequencies found that such parameters could improve symptoms of nausea and vomiting. ${ }^{17,18}$ The low power consumption of this type of pulses allowed for implantation of pulse generators that were small enough to contain current battery design, and made the technology available for clinical use. Based on the clinical studies that followed, the Food and Drug Administration (FDA) granted the implantation system (Enterra ${ }^{\mathrm{TM}}$ ) a

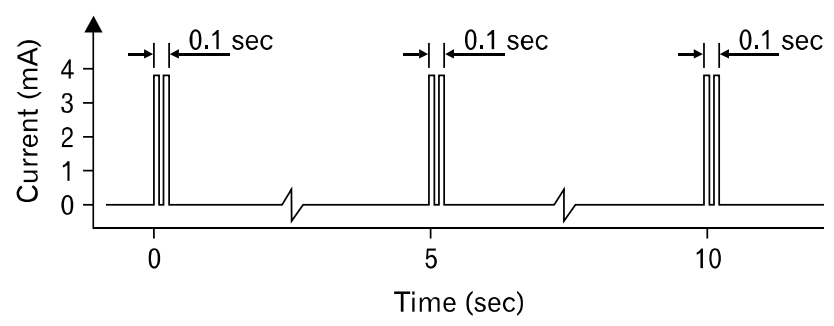

Figure 2. An illustration of the type of electrical stimulation used by the Enterra system. Short bursts of short duration rectangular pulses (330 $\mu$ s each) are given at a frequency of $14 \mathrm{~Hz}$ in each burst. Bursts in turn last 0.1 seconds, and are delivered every 5 seconds. This type of stimulus is referred to as short pulse duration/high frequency, and also as low energy. 
Humanitarian Use Device status, as a treatment for uncommon conditions for which no effective therapy is available. The Enterra system (Medtronic, Minneapolis, MN, USA) is the only system approved for clinical use. Currently, per FDA criteria, GES is approved for patients with idiopathic or diabetic gastroparesis, with severe symptoms that have not responded to maximal medical therapy. However, by the authors' experience, patients are frequently referred for consideration of GES after treatment with a single pharmacological agent, and little attention to dietary modifications. Every effort should be made to educate patients about proper gatsroparetic diet, and to maximize pharmacologic therapy by providing medication in adequate strength, mode of delivery (liquid, orally disintegrated form or by rectal route) and in combination. Adequate glucose control is imperative in diabetic patients. Only after all such measures fail to control symptoms, should GES be considered.

\section{Equipment and Implantation Procedure}

The Enterra gastric stimulation system consists of 3 main elements: a pair of leads, a pulse generator and a programming system. Two leads are surgically placed in the gastric wall, on the greater curvature, $10 \mathrm{~cm}$ proximal to the pylorus. The leads are connected to a pulse generator, placed in a subcutaneous pocket in the abdominal wall, in the left or right upper quadrants. The pulse generator was adapted from existing devices in clinical use, that could sustain long-term requirements of a low energy type of stimulation. The permanent implantable pulse generator is controlled by an external programmer, which allows for interrogation and programming of stimulation parameters via a radio-telemetry link. The pulse generator is programmed to specific parameters, as shown in Figure 2. These parameters have been derived from earlier canine and human studies. ${ }^{17,18}$

The Enterra system is implanted surgically, by laparotomy or increasingly by laparoscopy. Hospital stay following laparoscopic insertion is short, approximately 2 days ${ }^{19}$ and is shorter when compared to placement via laparotomy. ${ }^{20}$ The battery life extends to 5-10 years, depending on the pulse parameters used. ${ }^{21}$ When the battery is depleted, the pulse generator is replaced by local intervention.

\section{Clinical Experience With Gastric Electrical Stimulation}

Published data on GES for gastroparesis are derived almost entirely from open label studies, mostly performed in a selective number of centers with large experience in this therapy. ${ }^{19,22-30}$ Published studies consistently demonstrate that GES has a beneficial effect in patients with gastroparesis. The few studies that had a double blind phase reported comparable outcome, ${ }^{23,30}$ but their results were questioned because of study design issues. Besides the improvement in symptoms, GES was found to improve nutritional status ${ }^{22,31}$ and quality of life. ${ }^{23,32}$ GES was also found to reduce utilization of health care facilities and consequently to reduce health care costs associated with gastroparesis. ${ }^{33,34}$ Table provides a more detailed information from leading studies. Lately, the use of GES was expanded to etiologies beyond diabetic and idiopathic gastroparesis. GES was tried in post-surgical gastroparesis, ${ }^{35-37}$ intestinal pseudo-obstruction $^{38}$ and post organ transplant, ${ }^{39}$ with encouraging results. Data, however, are too few, and more studies are needed to determine the efficacy of GES in these groups of patients.

Different concepts of stimulation are also being investigated in order to maximize efficacy. A variation on the single channel gastric stimulation is achieved by the use of a number of electrodes, positioned at intervals along the long axis of the stomach with application of sequential stimulation intended to entrain gastric slow waves and to induce a propagated electrical and contractile sequence. Multichannel pacing requires a fraction of the energy used in single channel pacing, ${ }^{40}$ and it improves gastric emptying and symptoms in experimental models of gastroparesis ${ }^{41}$ and in diabetic patients with gastroparesis. ${ }^{42}$ A different approach was used in an animal model delivered with high frequency stimulation (microprocessor-controlled, phase-locked bipolar trains of pulses at a frequency of $50 \mathrm{~Hz}, 8-14 \mathrm{~V}$ ), applied to electrodes that were placed circumferentially along the distal stomach. Sequential stimulation resulted in sequential contractions that enhanced gastric emptying. ${ }^{43}$ Unlike the approved high frequency system (Enterra ${ }^{\mathrm{TM}}$ ), which is implanted in thousands of patients and with long-term results from multiple studies, these recent concepts of stimulation have been studied in a handful of subjects, or solely in the animal models. Therefore their technical feasibility and clinical efficacy remain to be explored in clinical trials.

Long-term studies report a complication rate of $7 \%-10 \%$, the main one being the infection on subcutaneous pocket. ${ }^{22,44,45}$ Less common complications include erosion of the abdominal wall by the device, penetration of the leads through the gastric wall, or tangling of wires in the generator pocket and formation of adhesions. These complications are generally managed surgically. In case of the infection on pocket, the pulse generator needs to be removed; however, it can be reinserted once the infection is fully 
Table. Studies of Gastric Electrical Stimulation for the Treatment of Gastroparesis

\begin{tabular}{|c|c|c|c|c|}
\hline References & Study & Follow-up & Patients (n) & Results/Outcomes \\
\hline Abell et al, ${ }^{23} 2003$ & $\begin{array}{l}\text { Multicenter, prospective, double- } \\
\text { blind placebo-controlled phase of } \\
1 \text { month, followed by open label } \\
\text { phase. } \\
\text { Aim: Evaluate the long term effect } \\
\text { of GES on GI Symptoms. }\end{array}$ & $1 \mathrm{yr}$ & $33(17 \mathrm{DG}, 16 \mathrm{IG})$ & $\begin{array}{l}\text { Significant improvement in vomiting } \\
\text { frequency and TSS in the first phase. } \\
\text { Significant improvement in vomiting, } \\
\text { TSS and QOL during open label } \\
\text { phase. }\end{array}$ \\
\hline Anand et al, ${ }^{44} 2007$ & $\begin{array}{l}\text { Open label study from } 3 \text { regional } \\
\text { centers. } \\
\text { Evaluation of long-term effects of } \\
\text { GES on symptoms, QOL and } \\
\text { survival. }\end{array}$ & Median of $4 \mathrm{yr}$ & $\begin{array}{l}214 \text { (156 with permanent } \\
\text { implantation) } \\
45 \text { DG, } 146 \text { IG, } 23 \\
\text { Post-surgical }\end{array}$ & $\begin{array}{l}\text { Significant improvement in vomiting } \\
\text { frequency, TSS and QOL. }\end{array}$ \\
\hline Abell et al, 2002 & $\begin{array}{l}\text { Open label, prospective, multicenter } \\
\text { study, with temporary GES in the } \\
\text { first phase. Evaluation of } \\
\text { permanent GES in patients who } \\
\text { responded to temporary GES. }\end{array}$ & $1 \mathrm{yr}$ & $\begin{array}{l}38 \text { (9 DG, } 24 \mathrm{IG}, 5 \\
\text { Post-surgical) }\end{array}$ & $\begin{array}{l}\text { Marked reduction }(>80 \%) \text { in nausea } \\
\text { and vomiting in } 33 \text { patients. } \\
\text { Alternative nutrition discontinued in } \\
9 / 14 \text {. }\end{array}$ \\
\hline Cutts et al, ${ }^{24} 2005$ & $\begin{array}{l}\text { Evaluation of long-term effects of } \\
\text { GES vs medical therapy on } \\
\text { symptoms, QOL and costs. }\end{array}$ & $3 \mathrm{yr}$ & $\begin{array}{l}18 \text { (2 DG, } 16 \text { IG). } \\
9 \text { had GES, control } \\
\text { group of } 9 \text { patients on } \\
\text { medical therapy. }\end{array}$ & $\begin{array}{l}\text { Better control of symptoms and lower } \\
\text { health care costs in the GES group. }\end{array}$ \\
\hline Gourcerol et al, ${ }^{26} 2007$ & $\begin{array}{l}\text { Evaluation of GES in patients with } \\
\text { delayed vs. normal gastric } \\
\text { emptying. }\end{array}$ & $6 \mathrm{mo}$ & $\begin{array}{l}15 \text { (7 with normal } \\
\text { emptying, } 8 \text { with } \\
\text { delayed) }\end{array}$ & $\begin{array}{l}\text { Comparable improvement in symptoms } \\
\text { and QOL in both groups. }\end{array}$ \\
\hline Islam et al, ${ }^{27} 2008$ & $\begin{array}{l}\text { Evaluation of GES in pediatric } \\
\text { population. }\end{array}$ & $8-42$ mo & 9 (average age, $14 \mathrm{yr}$ ) & Improvement in symptoms and QOL. \\
\hline Maranki et al, ${ }^{34} 2008$ & $\begin{array}{l}\text { Describe predictive factors for } \\
\text { outcome of GES. }\end{array}$ & $5 \mathrm{mo}$ & $28(16 \mathrm{IG}, 12 \mathrm{DG})$ & $\begin{array}{l}\text { Improvement in nausea and vomiting, } \\
\text { but not in bloating or abdominal pain. } \\
\text { Use of opiates associated with poor } \\
\text { response. Better response in diabetic } \\
\text { compared to idiopathic group. }\end{array}$ \\
\hline $\begin{array}{l}\text { McCallum et al, } \\
2005\end{array}$ & $\begin{array}{l}\text { Evaluation of GES in post-surgical } \\
\text { patients. }\end{array}$ & $1 \mathrm{yr}$ & 16 & $\begin{array}{l}\text { Improvement in symptoms and QOL } \\
\text { and reduced hospitalizations and } \\
\text { health care costs. Alternative nutrition } \\
\text { discontinued in } 4 \text { patients. }\end{array}$ \\
\hline Salameh et al, ${ }^{37} 2007$ & $\begin{array}{l}\text { Evaluation of GES in patients with } \\
\text { post Roux-en-Y gastric bypass. }\end{array}$ & $6 \mathrm{mo}$ & 5 & Improvement in symptoms and TSS. \\
\hline Lin et $\mathrm{al}^{31} 2006$ & $\begin{array}{l}\text { Evaluation of long-term outcome of } \\
\text { GES. }\end{array}$ & $\geq 3 \mathrm{yr}$ & $\begin{array}{l}55(39 \mathrm{DG}, 9 \mathrm{IG}, 7 \\
\text { post-surgical) }\end{array}$ & $\begin{array}{l}\text { Improvement in TSS, sustained. } \\
\text { Reduced hospitalizations, use of } \\
\text { medications and need for alternative } \\
\text { nutrition. Diabetic patients showed a } \\
\text { significant reduction in HbA1C from } \\
\text { 9.5\% to } 7.9 \% \text {. }\end{array}$ \\
\hline Mason et al, ${ }^{28} 2005$ & $\begin{array}{l}\text { Evaluation of the effect of GES on } \\
\text { symptoms of gastroparesis. }\end{array}$ & $20 \mathrm{mo}$ & $29(24 \mathrm{DG}, 5 \mathrm{IG})$ & $\begin{array}{l}\text { Significant increase in BMI, } 70 \% \\
\text { reported good to excellent outcome, } \\
\text { reduced need for alternative nutrition. }\end{array}$ \\
\hline Brody et al, ${ }^{19} 2008$ & $\begin{array}{l}\text { Evaluation of the effect of GES on } \\
\text { symptoms of gastroparesis. }\end{array}$ & $12 \mathrm{mo}$ & $\begin{array}{l}50 \text { (20 DG, } 25 \mathrm{IG}, 2 \text { post } \\
\text { surgical, } 3 \text { connective } \\
\text { tissue disorder) }\end{array}$ & $\begin{array}{l}\text { Significant improvement in nausea, } \\
\text { vomiting and TSS. }\end{array}$ \\
\hline McKenna et al, ${ }^{29} 2008$ & $\begin{array}{l}\text { Evaluation of the effect of GES on } \\
\text { symptoms of gastroparesis. }\end{array}$ & $\begin{array}{l}\text { Mean follow-up, } \\
38 \mathrm{wk}\end{array}$ & $\begin{array}{l}19 \text { (10 DG, } 6 \mathrm{IG}, 3 \text { post } \\
\text { surgical) }\end{array}$ & $\begin{array}{l}\text { Improvement in symptoms and TSS, } \\
\text { but not in QOL. }\end{array}$ \\
\hline
\end{tabular}

GES, gastric electrical stimulation; GI, gastrointestinal; DG, diabetic gastroparesis; IG, idiopathic gastroparesis; TSS, total symptom score; QOL, quality of life; HbA1C, hemoglobin A1C; BMI, body mass index. 
controlled. $^{44}$

Given the invasive nature of this intervention, efforts were made to identify factors that can predict good response to therapy. A few clinical features were found to be associated with less than optimal response, such as the use of opiates, ${ }^{46}$ and idiopathic, rather than diabetic etiology. ${ }^{23,34}$ Pain and bloating were not improved compared with nausea and vomiting. ${ }^{46}$ Thus, diabetic patients with gastroparesis, with nausea and vomiting as their predominant symptoms, appeared to be the best candidates for GES. Unfortunately, individual response to GES remains unpredictable. The need to predict response generated an interest in the use of temporary gastric electrical stimulation, using trans-nasal mucosal electrodes, assessing the response to a few days of therapy as a predictor of response to long term therapy with the Enterra system, ${ }^{47}$ but there are no data available so far from double blind, control studies to support its use for such purpose. Also, once implantation is performed, there is no clear strategy for addressing patients who do not respond to GES. Various manipulations of pulse parameters have been suggested ${ }^{48}$ but data are not yet sufficient to support such approach.

\section{Mechanisms of Gastric Electrical Stimulation}

In general, electrical stimulation of gut tissue can modulate the neuromuscular function of the organs involved and/or affect afferent neural activity emanating from the organs. This concept has been tested in both animal models and humans, however, the mechanisms of action of GES in gastroparesis remain poorly understood. Studies in animals ${ }^{1}$ and later in humans ${ }^{2}$ have clearly shown that entrainment (pacing) of gastric slow waves could be achieved with GES using low-frequency/long-duration pulse parameters, and that these parameters could enhance gastric emptying. ${ }^{3,4}$ Initial reports from animal and human studies suggested that similar effects can be achieved with GES when using short-duration pulses. ${ }^{17,18}$ However, subsequent studies, using the pulse parameters of the implantable Enterra system, did not support these initial observations. Enterra parameters did not control vasopressin-induced gastric dysrhythmia in an animal model, though it improved vomiting, ${ }^{49}$ while in humans, GES did not affect gastric electrical activity in patients with gastroparesis, as measured by electrogastrography. ${ }^{50}$ The effect of GES on gastric emptying is inconsistent, with some studies showing enhancement of gastric emptying, ${ }^{19,25}$ observed only in diabetics, ${ }^{23}$ or no improvement. ${ }^{45,51}$ Given the variable correlation between gastric emptying and symptoms of gastroparesis, ${ }^{52}$ and keeping in mind the possibility of spontaneous resolution of idiopathic gastroparesis over time, ${ }^{53}$ the system should not be used to achieve a prokinetic effect, such as to treat patients who suffer from gastric bezoars or severe gastroesophageal reflux disease.

A more plausible mechanism is perhaps the effect of GES on gastric biomechanical activity. Both, low-frequency/long-duration and high-frequency/short-duration pulses were shown to reduce gastric tone in animal models ${ }^{54,55}$ and reduced symptoms induced by gastric distension. ${ }^{55}$ Impairment of gastric accommodation has been documented in patients with functional dyspepsia and diabetic gastropathy, ${ }^{56,57}$ and such impairment in turn was associated with gastrointestinal symptoms, primarily early satiety and weight loss, ${ }^{56}$ suggesting a possible mechanism for GES in symptom relief. The afferent modulation and central mechanism of GES remain unclear. In dogs, the antiemetic effect is vagally mediated, since it is abolished by vagal disruption, ${ }^{49}$ but GES was also shown to improve symptoms in post surgical gastroparesis, some with vagal disruption. ${ }^{35-37}$ GES was found to increase activity in the thalamus of patients with gastroparesis, as detected by positron emission tomography. ${ }^{58}$ These data are difficult to interpret, particularly since perturbation of the gut is likely to have a central representation, and hence its mere presence may not necessarily indicate a neural mechanism.

\section{Areas of Uncertainty}

In spite of the encouraging data provided by the studies published so far, there remains an element of skepticism with regard to this intervention, ${ }^{59}$ driven by the lack of a convincing double blind, placebo (sham-stimulation) controlled study, sufficiently powered to provide conclusive data regarding the efficacy. However, clinical experience, and most importantly, the lack of the effective therapy for gastroparesis, support the use of GES in refractory patients with debilitating symptoms who exhausted all available medical regimens. The lack of reliable measures to predict response to therapy in individual patients, particularly given the invasive nature of this intervention, continues to limit the application of this intervention.

\section{Conclusion}

Considerable clinical evidences support the use of GES for the treatment of drug refractory gastroparesis. The Enterra system is the only one approved for such purpose. Improvement of 
pulse parameters, the potential use of temporary stimulation and the incorporation of variables that can predict better response to stimulation may improve the efficacy of the current system. New systems under investigation may prove to be more efficacious and provide better control of symptoms coupled with prokinetic effect.

\section{References}

1. Kelly KA, La Force RC. Pacing the canine stomach with electrical stimulation. Am J Physiol 1972;222:588-594.

2. Lin ZY, McCallum RW, Schirmer BD, Chen JD. Effects of pacing parameters in the entrainment of gastric slow waves in patients with gastroparesis. Am J Physiol 1998;274(1 Pt 1):G186-G191.

3. Eagon JC, Kelly KA. Effects of gastric pacing on canine gastric motility and emptying. Am J Physiol 1993;265(4 Pt 1):G767-G774.

4. McCallum RW, Chen JDZ, Lin ZY, Schirmer BD, Williams RD, Ross RA. Gastric pacing improves gastric emptying and symptoms in patients with gastroparesis. Gastroenterology 1998;114:456-461.

5. Hocking MP, Vogel SB, Sninsky CA. Human gastric myoelectrical activity and gastric emptying following gastric surgery and with pacing. Gastroenterology 1992;103:1811-1816.

6. Miedema BW, Sarr MG, Kelly KA. Pacing the human stomach. Surgery 1992;111:143-150.

7. Merril DR, Bikson M, Jefferys JG. Electrical stimulation of excitable tissue: design of efficacious and safe protocols. J Neurosci Methods 2005;141:171-198.

8. Prutchi D, Norris M. Design and development of medical electronic instrumentation: a practical perspective of the design, construction, and test of medical devices. Wiley-Interscience 2004.

9. Bilgutay AM, Wingrove R, Grifen WO, Bonnabeau RC Jr, Lillehei CW. Gastro-intestinal pacing: a new concept in the treatment of ileus. Ann Surg 1963;158:338-348.

10. Quast DC, Beall AC Jr, DeBakey ME. Clinical evaluation of the gastrointestinal pacer. Surg Gynecol Obstet 1965;120:35-37.

11. Berger T, Kewenter J, Kock NG. Response to gastrointestinal pacing: antral, duodenal and jejunal motility in control and postoperative patients. Ann Surg 1966;164:139-144.

12. Sarna SK. Gastrointestinal electrical activity: terminology. Gastroenterology 1975;68:1631-1635.

13. Hinder RA, Kelly KA. Human gastric pacemaker potential: Site of origin, spread, and response to gastric transaction and proximal gastric vagotomy. Am J Surg 1977;133:29-33.

14. Sarna SK, Bowes KL, Daniel EE. Gastric pacemakers. Gastroenterology 1976;70:226-231.

15. Bellahsène BE, Schirmer BD, Updike OL, McCallum RW. Effect of electrical stimulation on gastric emptying. Dig Dis Sci 1987;32: 902.

16. Bellahsène BE, Lind CD, Schirmer BD, Updike OL, McCallum RW. Acceleration of gastric emptying with electrical stimulation in a canine model of gastroparesis. Am J Physiol 1992;262(5 Pt 1):G826G834.

17. Familoni BO, Abell TL, Nemoto D, Voeller G, Johnson B. Efficacy of electrical stimulation at frequencies higher than basal rate in canine stomach. Dig Dis Sci 1997;42:892-897.
18. Familoni BO, Abell TL, Voeller G, Salem A, Gaber O. Electrical stimulation at a frequency higher than basal rate in human stomach. Dig Dis Sci 1997; 42:885-891.

19. Brody F, Vaziri K, Saddler A, et al. Gastric electrical stimulation for gastroparesis. J Am Coll Surg 2008;207:533-538.

20. Al-Jubury A, Granger S, Barnes J, et al. Laparoscopy shortens the length of stay in patients with gastric electrical stimulators. JSLS 2005;9:305-310.

21. Curuchi AP, Al-Juburi A, Familoni B, et al. Gastric electrical stimulation - a ten year experience. Gastroenterology 2004;126;A1284.

22. Abell T, Lou J, Tabbaa M, Batista O, Malinowski S, Al-Juburi A. Gastric electrical stimulation for gastroparesis improves nutritional parameters at short, intermediate, and long-term follow-up. JPEN J Parenter Enteral Nutr 2003;27: 277-281.

23. Abell T, McCallum R, Hocking M, et al. Gastric Electrical Stimulation for Medically Refractory Gastroparesis. Gastroenterology 2003;125:421-428.

24. Cutts TF, Luo J, Starkebaum W, Rashed H, Abell TL. Is gastric electrical stimulation is superior to standard pharmacologic therapy in improving GI symptoms, healthcare resources, and long-term health care costs? Neurogastroenterol Motil 2005;17:35-43.

25. Abell T, Van Custem E, Abrahamsson H, et al. Gastric electrical stimulation in intractable symptomatic gastroparesis. Digestion 2002; 66:204-212

26. Gourcerol G, Leblanc I, Leroi AM, Denis P, Ducrotte P. Gastric electrical stimulation in medically refractory nausea and vomiting. Eur J Gastroenterol Hepatol 2007;19:29-35.

27. Islam S, Vick LR, Runnels MJ, Gosche JR, Abell T. Gastric electrical stimulation for children with intractable nausea and gastroparesis. J Pediatr Surg 2008;43:437-442.

28. Mason RJ, Lipham J, Eckerling G, Schwartz A, Demeester TR. Gastric electrical stimulation: an alternative surgical therapy for patients with gastroparesis. Arch Surg 2005;140:841-846; discussion 847-848.

29. McKenna D, Beverstein G, Reichelderfer M, Gaumnitz E, Gould J. Gastric electrical stimulation is an effective and safe treatment for medically refractory gastroparesis. Surgery 2008;144:566-574.

30. McCallum RW, Snape W, Brody F, et al. Gastric electrical stimulation with Enterra therapy improves symptoms from diabetic gastroparesis in a prospective study. Clin Gastroenterol Hepatol 2010;8: 947-954.

31. Lin Z, Sarosiek I, Forster J, McCallum RW. Symptom responses, long-term outcomes and adverse events beyond 3 years of high-frequency gastric electrical stimulation for gastroparesis. Neurogastroenterol Motil 2006;18:18-27.

32. Forester J, Sarosiek I, Lin Z, et al. Further experience with gastric stimulation to treat drug refractory gastroparesis. Am J Surg 2003; 186:690-695.

33. Lin Z, McElhinney C, Sarosiek I, Forster J, McCallum R. Chronic gastric electrical stimulation for gastroparesis reduces the use of prokinetic and/or antiemetic medications and the need for hospitalizations. Dig Dis Sci 2005;50:1328-1334.

34. Maranki JL, Lytes V, Meilahn JE, et al. Predictive factors for clinical improvement with Enterra gastric electric stimulation treatment for refractory gastroparesis. Dig Dis Sci 2008;53:2072-2078.

35. McCallum RW, Lin Z, Wetzl P, Sarosiek I, Forster J. Clinical re- 
sponse to gastric electrical stimulation in patients with postsurgical gastroparesis. Clin Gastroenterol Hepatol 2005;3:49-54.

36. Oubre B, Luo J, Al-Juburi A, Voeller G, Familoni B, Abell TL. Pilot study on gastric electrical stimulation on surgery-associated gastroparesis: long-term outcome. South Med J 2005;98:693-697.

37. Salameh J, Schmieg RE Jr, Runnels JM, Abell TL. Refractory gastroparesis after Roux-en-Y gastric bypass: surgical treatment with implantable pacemaker. J Gastrointest Surg 2007;11:1669-1672.

38. Andersson S, Lönrot H, Simrén M, Ringström G, Elfvin A, Abrahamsson $\mathrm{H}$. Gastric electrical stimulation for intractable vomiting in patients with chronic intestinal pseudiobstruction. Neurogastroenterol Motil 2006;18:823-830.

39. Filichia LA, Cendan JC. Small case series of gastric electrical stimulation for the management of transplant-induced gastroparesis. J Surg Res 2008;148:90-93.

40. Chen JD, Xu X, Zhang J, et al. Efficiency and efficacy of multi-channel gastric electrical stimulation. Neurogastroenterol Motil 2005;17: 878-882.

41. Song G, Hou X, Yang B, Liu J, Qian W, Chen JD. Two-channel gastric electrical stimulation accelerates delayed gastric emptying induced by vasopressin. Dig Dis Sci 2005;50:662-668.

42. Sarosiek I, Forester J, Roeser k, et al. Effect of multi-point gastric electrical pacing (MGP) on symptoms, gastric emptying and electrical activity in diabetic gastroparesis. Gastroenterology 2008;134: A847.

43. Mintchev MP, Sanmiguel CP, Amaris M, Bowes KL. Microprocessor-controlled movement of solid gastric content using sequential neural electrical stimulation. Gastroenterology 2000;118:258-263.

44. Anand C, Al-Juburi A, Familoni B, et al. Gastric electrical stimulation is safe and effective: a long-term study in patients with drug-refractory gastroparesis in three regional centers. Digestion 2007;75:83-89.

45. McCallum RW, Lin Z, Forster J, Roesser K, Hou Q, Sarosiek I. Gastric electrical stimulation improves outcomes of patients with gastroparesis for up to 10 years. Clin Gastroenterol Hepatol 2011;9: 314-319.e1.

46. Forster J, Damjanov I, Lin Z, Sarosiek I, Wetzel P, McCallum RW. Absence of the interstitial cells of Cajal in patients with gastroparesis and correlation with clinical findings. J Gastrointest Surg 2005;9: 102-108.

47. Ayinala S, Bastita O, Goyal A, et al. Temporary gastric electrical stimulation can be safely performed with oral or PEG placed electrodes in patients with drug refractory gastroparesis. J Gastrointest Endosc 2005;61:455-461.

48. Abidi N, Starkebaum WL, Abell TL. An energy algorithm improves symptoms in some patients with gastroparesis and treated with gastric electrical stimulation. Neurogastroenterol Motil 2006;18:334-338.

49. Chen JD, Qian L, Ouyang H, Yin J. Gastric electrical stimulation with short pulses reduces vomiting but not dysrhythmia in dogs. Gastroenterolgy 2003;124:401-409.

50. Lin Z, Forster J, Sarosiek I, McCallum RW. Effect of high-frequency gastric electrical stimulation on gastric myoeleftrical activity in gastroparetic patients. Neurogastroenterol Motil 2004;16:205212.

51. Lin Z, Forster J, Sarosiek I, McCallum RW. Treatment of gastroparesis by high-frequency gastric electrical stimulation. Diabetes Care 2004;27:1071-1076.

52. Horowitz M, Harding PE, Maddox AF, et al. Gastric and esophageal emptying in patients with type 2 (non insulin-dependent) diabetes mellitus. Diabetologia 1989;32:151-159.

53. Bityutskiy LP, Soykan I, McCallum RW. Viral astroparesis; a subgroup of idiopathic gastroparesis-clinical characteristics and long-term outcomes. Am J Gastroenterol 1997;92:1501-1504.

54. Xing JH, Brody F, Brodsky J, Larive B, Ponsky J, Soffer E. Gastric electrical stimulation at proximal stomach induces gastric relaxation in dogs. Neurogastroenterol Motil 2003;15:15-23.

55. Xing JH, Chen JD. Gastric electrical stimulation with parameters of gastroparesis enhances gastric accommodation and alleviates distension-induced symptoms in dogs. Dig Dis Sci 2006;51:2160-2164.

56. Tack J, Piessevaux H, Coulie B, Caenepeel P, Janssens J. Role of impaired gastric accommodation to a meal in functional dyspepsia. Gastroenterology 1998;115:1346-1352.

57. Samson M, Roelfus JM, Akkermans LM, van Berge Henegouwen GP, Smout AJ. Proximal gastric motor activity in response to a liquid meal in type 1 diabetes mellitus with autonomic neuropathy. Dig Dis Sci 1998;43:491-496.

58. McCallum RW, Dusing RW, Sarosiek I, Cocjin J, Forster J, Lin Z. Mechanisms of high-frequency electrical stimulation in the stomach in gastroparetic patients. Conf Proc IEEE Eng Med Biol Soc 2006; 1:5400-5403.

59. Stanghellini V. Unfulfilled wishes by gastric electrical stimulation. Clin Gastroenterol Hepatol 2011;9:447-448; author reply 448-449. 